\title{
TOTAL PHENOLIC CONTENT AND ANTIOXIDANT ACTIVITIES IN CALLUS OF KAEMPFERIA PARVIFLORA
}

\author{
Zuraida Ab Rahman ${ }^{1}$, Ayu Nazreena Othman ${ }^{1}$, Chandradevan A/L Machap ${ }^{1}$, Amirah \\ Balqis Amir Amran ${ }^{2}$ and Nur Najwa Arifah Basiron ${ }^{1}$
${ }^{1}$ Biotechnology \& Nanotechnology Research Centre, Malaysian Agricultural Research and Development Institute, MARDI HQ, Persiaran MARDI-UPM, Serdang Selangor, 43400, Malaysia
${ }^{2}$ School of Agriculture Science \& Biotechnology, Faculty of Bioresources and Food Industry, Universiti Sultan Zainal Abidin, Besut Campus, 22200, Besut, Terengganu, Malaysia
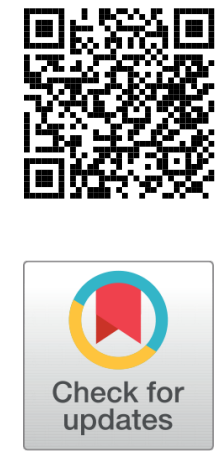

Received 28 May 2021

Accepted 13 June 2021

Published 30 June 2021

Corresponding Author

Zuraida Ab Rahman, azuraida@m

ardi.gov.my

DOI $10.29121 /$

granthaalayah.v9.i6.2021.3992

Funding: This research received no specific grant from any funding agency in the public, commercial, or not-for-profit sectors.

Copyright: (C) 2021 The Author(s). This is an open access article distributed under the terms of the Creative Commons Attribution License, which permits unrestricted use, distribution, and reproduction in any medium, provided the original author and source are credited.

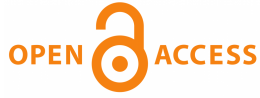

\section{ABSTRACT}

Black ginger or Kaempferia parviflora is one useful medicinal plant that urges the need to be cultivated widely. This plant has some previous studies about their rhizomes and callus growth optimization, but their total phenolic content and antioxidant activities are not very well known. This study aims to study the total phenolic content and antioxidant activities of callus of K.parviflora. This study is to determine the type and concentration of hormone that give the best effect on the growth of callus in vitro culture from different parts (meristem, and basal part) of K.parviflora. Different concentrations were tested with medium 2,4-dichlorophenoxyacetic acid (2,4-D) and napthyleneacetic acid (NAA) in callus cultivation. The highest total phenolic content tested in callus is one with $10.00 \mathrm{mg} / \mathrm{L} \mathrm{2,4-D}$ from the meristem part of the plant. The highest antioxidant activity is from the meristem part of the plant with $5.00 \mathrm{mg} / \mathrm{L} 2,4-\mathrm{D}$.

Keywords: Kaempferia Parviflora, Callus Induction, Phenolic Content, Antioxidant Activities

\section{INTRODUCTION}

The ginger plant Kaempferia parviflora belongs to the Zingiberaceae family. It is also known as "kunyit hitam" in Malay, and Krachai-dam in the Thai language. This plant has long been utilized in Malay and Thai medicine to promote health, relieve body pains, treat leucorrhea, mouth disease, gastrointestinal issues, and correct male impotence Tewtrakul et al. (2008a), Rujjanawate et al. (2005). K. parviflora has been proven by studies to have anti-allergic Tewtrakul et al. (2008b), anti-fungal Yenjai et al. (2004), anti-ulcer Rujjanawate et al. (2005), and antimicrobial properties Yenjai et al. (2004). Wide medicinal usage of K. parviflora made this plant have high needs to be cultivated widely. The issue of having a low supply of high-quality stock 
triggered the effort to study the production of high-quality K. parviflora. There are studies of producing K. parviflora by in vitro culture Prathanturarug et al. (2000). The availability of superior seeds in large quantities and pathogens free depends on the type and concentration of hormone added to the media Sumadi (2020). Phenolic compound plays a vital role in having anti-microbial and anti-fungal properties as they have these redox properties, which plays an important role in absorbing and neutralizing free radicals, quenching singlet and triplet oxygen, or decomposing peroxide Ghasemzadeh et al. (2010). Many authors suggested that total phenolic content has a direct link to antioxidant activities because of phenolic compounds, due to their hydroxyl groups which have a high scavenging capacity to combat free radicals.

This study aims to determine the best concentration of mediums that give a positive effect on callus from different parts of K. parviflora (meristem and basal part). In plants, the meristem is an area of cells capable of division and growth. They are classified by their location in the plant as apical (located at the root and shoot tips), lateral (in the vascular and cork cambia), and intercalary (at internodes, or stem regions between the places at which leaves attach or leaf bases) Britannica (2020). While the basal part is defined as the lowest or bottom part of an object on which it stands or the main part to which other parts are added Baluška et al. (2005). Mediums used contain two types of auxin hormone which are 2,4-dichlorophenoxyacetic acid (2,4-D) and napthyleneacetic acid (NAA) with different concentrations $(0.2 \mathrm{mg} / \mathrm{L}, 0.5 \mathrm{mg} / \mathrm{L}$, $1.0 \mathrm{mg} / \mathrm{L}, 3.0 \mathrm{mg} / \mathrm{L}, 5.0 \mathrm{mg} / \mathrm{L}$ and $10 \mathrm{mg} / \mathrm{L})$.

\section{MATERIALS AND METHODS}

\subsection{INITIAL CULTURES ESTABLISHMENT}

The cultivation of Kaempferia parviflora took place inside a glasshouse located at the Malaysian Agriculture Research and Development Institute (MARDI), Serdang. The shoots of the plants were then collected and act as explants. The shoots were cleaned under running tap water for an hour. The cleaning process was followed by commercial laboratory detergent and rinsed with water. water. The explants were submerged in $1 \%\left(\mathrm{v} / \mathrm{v}\right.$ ) of fungicide (Benomyl $50 \%$, Benlate ${ }^{\circledR}$ ) for an hour and then proceed with rinsing of tap water. Subsequently, Clorox was used as part of the sterilization process and followed by a few rounds of cleaning and rinsing with sterile distilled water. A sterile surgical blade was used to cut the leaf sheath present on the buds of Kaempferia parviflora. The explants were inoculated onto basal Murashige and Skoog's (1962) medium with $3.0 \mathrm{mg} / \mathrm{L}$ of benzyl aminopurine (BAP) for the production of plantlets of Kaempferia parviflora. The $\mathrm{pH}$ was adjusted to 5.8 and eventually followed by autoclaving at $121^{\circ} \mathrm{C}$ under $1.05 \mathrm{~kg} / \mathrm{cm}^{2}$ for 15 minutes. The cultures were grown under white fluorescent light $(3,000 \mathrm{lux})$ with a photoperiod duration of 16 hours light and 8 hours darkness at $25 \pm 2{ }^{\circ} \mathrm{C}$. The plantlets cultured in vitro were used to induce callus. 


\subsection{CALLUS INDUCTION}

Callus induction of Kaempferia parviflora initially started with plantlets that were grown in vitro and two parts of the explants which are the meristem and basal part were sub-cultured separately inside a $150 \mathrm{ml}$ flask with a liquid medium consisting of MS medium supplemented with $60 \%$ sucrose for callus induction with two treatments which are 2,4-D and NAA with a variety of concentration $(0.2 \mathrm{mg} / \mathrm{L}, 0.5 \mathrm{mg} / \mathrm{L}$, $1.0 \mathrm{mg} / \mathrm{L}, 3.0 \mathrm{mg} / \mathrm{L}, 5.0 \mathrm{mg} / \mathrm{L}, 10.0 \mathrm{mg} / \mathrm{L}$ ). The plantlets were sub-cultured every month interval for three months. After three months, the callus was dried at a temperature of $40{ }^{\circ} \mathrm{C}-50^{\circ} \mathrm{C}$ for three days.

\subsection{DETERMINATION OF PHENOLIC CONTENT}

The total phenolic content (TPC) of the dried callus was determined using the FolinCiocalteu (FC) method. Approximately $0.1 \mathrm{~g}$ of dry callus were added to $0.2 \mathrm{ml}$ of FC reagent (5-fold diluted with distilled water). The mixture was shaken for 3 minutes and then sodium carbonate with a volume of $0.2 \mathrm{ml}(10 \% \mathrm{w} / \mathrm{v})$ was added. Under the dark condition, the mixture was left to stand for 30 minutes. The absorbance was read using Jasco V-550 UV-VIS spectrophotometer at $760 \mathrm{~nm}$. TPC was expressed as milligram gallic acid equivalent per gram dry extract (mg GAE/mg dry extract).

\subsection{DETERMINATION OF ANTIOXIDANT ACTIVITY}

DPPH radical scavenging assay was used to determine the antioxidant activity of the basal part and the meristem of the callus. $0.5 \mathrm{ml}$ of callus extract along with $4.5 \mathrm{ml}$ of DPPH were put inside $250 \mathrm{ml}$ flask and methanol was added. Subsequently, the mixture was shaken and left to stand at room temperature for 30 minutes under dark conditions. The antioxidant activity was determined at $517 \mathrm{~nm}$ against blank solvent. The antioxidant activity was recorded for different treatments with different concentrations for two different parts which are the meristem and basal part.

\section{RESULT AND DISCUSSION}

Based on a previous study, both culture media (2,4-D and NAA) are suitable for callus induction using shoot buds explants Zuraida et al. (2014). However, the matter of their phenolic content has not yet been discovered. Therefore, the purpose of this study is to identify the optimal concentration of media that produce the highest phenolic content and also antioxidant activities for both basal and meristem part of $\mathrm{K}$. parviflora.

As shown in Figure 1 , the meristem of $\mathrm{K}$. parviflora cultured on 2,4-D media with the concentration of $10.0 \mathrm{mg} / \mathrm{L}$ has the highest accumulation of phenolic compound (1340 U/g dry sample), while the basal part is at its highest accumulation with $5.0 \mathrm{mg} / \mathrm{L}$ of 2,4-D (653 U/g dry samples). On the other hand, the highest phenolic accumulation in NAA for meristem and basal part is at $10.0 \mathrm{mg} / \mathrm{L}$ where meristem recorded for $1198 \mathrm{U} / \mathrm{g}$ dry sample and basal part recorded for only $489 \mathrm{U} / \mathrm{g}$ dry sam- 
ples. Generally, callus cultured in NAA have lower phenolic content when compared with callus cultures in 2,4-D. However, in both meristem and basal parts at $1.0 \mathrm{mg} / \mathrm{L}$, NAA relatively has higher reading compared to 2,4-D with $942 \mathrm{U} / \mathrm{g}$ dry samples in 1.0 $\mathrm{mg} / \mathrm{L}$ of NAA compared to only $893 \mathrm{U} / \mathrm{g}$ dry samples in $1.0 \mathrm{mg} / \mathrm{L}$ of 2,4-D for meristem. A similar pattern can be observed also in $1.0 \mathrm{mg} / \mathrm{L}$ where $1.0 \mathrm{mg} / \mathrm{L}$ of NAA was recorded for $324 \mathrm{U} / \mathrm{g}$ dry samples compared with the readings recorded for $322 \mathrm{U} / \mathrm{g}$ dry samples at $1.0 \mathrm{mg} / \mathrm{L}$ of 2,4-D for the basal part.

Other than that, meristem parts are seen to produce greater phenolic content compared to the basal part. Phenolic content correlates with the antioxidant properties as phenolic content in the plants or this research is $\mathrm{K}$. parviflora have redox properties that can act as antioxidant Johari and Khong (2019). According to a study Vichitphan et al. (2007) that was also conducted on K. parviflora, phenolic content is the most crucial part in determining antioxidant potentials, and also in the same research proved a positive correlation between phenolic content and also antioxidant activity. A positive correlation can also be seen regarding the results obtained in this research whereby for meristem cultured in $5.0 \mathrm{mg} / \mathrm{L}$ of 2,4-D showed high antioxidant activity (114 U/g dry samples) with the phenolic content that is also high (1090 U/Gram Dry Sample). However, a positive correlation cannot be seen in $10.0 \mathrm{mg} / \mathrm{L}$ of 2,4-D where high phenolic content 1340 U/Gram Dry Sample have low antioxidant activity (76 U/Gram Dry Sample). This phenomenon may be caused by the breaking down of the phenolic compound whereby it oxidized which consequently inhibit the activity of antioxidant.

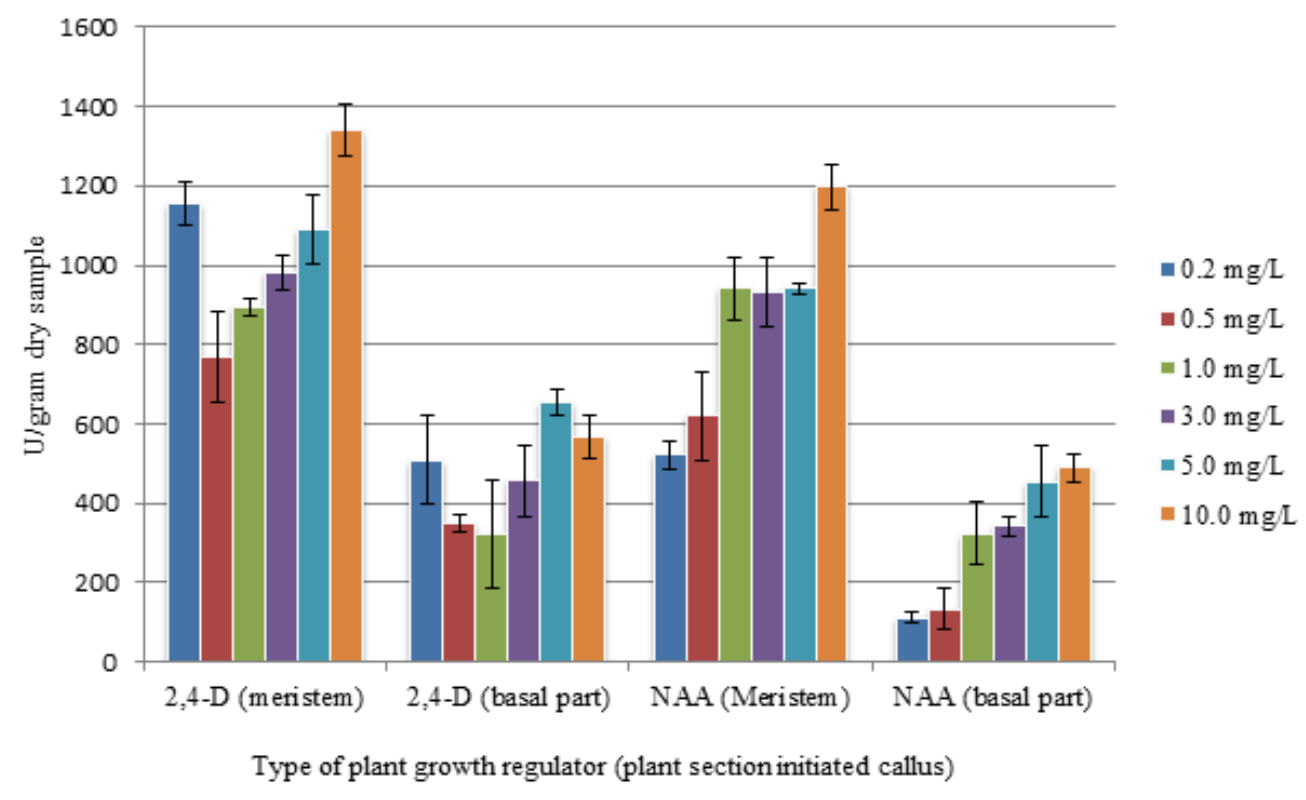

Figure 1 Total PhenolicContent in Callus of K. parviflora 
The antioxidant activities of two distinct parts (meristem and basal parts) of K. parviflora are shown in Figure 2. Callus from the meristem and basal parts K. parviflora are cultivated in various concentrations of 2,4-D and NAA media. The meristem of K. parviflora cultured on 2,4-D media with the concentration of $5.0 \mathrm{mg} / \mathrm{L}$ has the highest antioxidant activities among all other treatments (114 U/g dry samples) and as for the basal part, the highest reading is only at $39 \mathrm{U} / \mathrm{g}$ dry samples for $1.0 \mathrm{mg} / \mathrm{L}$ of 2,4-D. This indicates that the basal part does not contain as much antioxidant as the meristem. As for NAA, both meristem and basal parts peaked at $0.5 \mathrm{mg} / \mathrm{L}$ with results recorded at $108 \mathrm{U} / \mathrm{g}$ dry samples and $46 \mathrm{U} / \mathrm{g}$ dry samples respectively. However, in a comparison between both treatments for the basal part, NAA showed higher readings than 2,4-D with the readings recorded at $46 \mathrm{U} / \mathrm{g}$ dry samples at $5.0 \mathrm{mg} / \mathrm{L}$. As for meristem, when compared, $5.0 \mathrm{mg} / \mathrm{L}$ still showed the highest reading for antioxidant activity with $114 \mathrm{U} / \mathrm{g}$ dry samples but in this case, 2,4-D showed higher reading when compared to NAA (108 U/g dry samples).

Based on the results, it can be said that the $5.0 \mathrm{mg} / \mathrm{L}$ of 2,4-D is the optimal concentration to induce the highest amount of antioxidant activity in Kaempferia parviflora and from the results, it can be seen that meristem have better antioxidant content. However, a study PRIHANTINI et al. (2018) stated that NAA is better in callus induction but the research only used $0.5 \mathrm{mg} / \mathrm{L}$ of 2,4-D as the highest concentration for 2,4-D. On the other hand, this research proved that a high concentration of 2,4-D produced callus that contains high antioxidant activity and the results seem to be parallel with another study El-Nabarawy et al. (2015) that proved that $1.0 \mathrm{mg} / \mathrm{L}$ of 2,4-D but in a combination of $0.5 \mathrm{mg} / \mathrm{L} \mathrm{BA}$ are suitable for callus formation for ginger. Furthermore, the same study also stated that NAA, BA, or even the combination of both NAA and BA were unable to induce callus. Hence, proving a point that 2,4-D is suitable to produce callus and from the callus induction, antioxidant activity can be identified. In this research, meristem can be seen to be better than basal parts in producing higher antioxidant content. Similar findings can be seen in a study Jiménez-Aspee et al. (2018) that stated the meristem part has higher antioxidant activity compared to other parts of plants.

The success of micropropagation is dependent on several parameters, including plant growth regulators and the type of explants used Pati et al. (2006). Plant growth regulators operate as signals in the developmental processes of plants, stimulating, inhibiting, or regulating growth MERCIER et al. (1997). 2,4-D and NAA are types of auxin hormones which are growth hormones that are produced at the apical tips of the growing plants. An equal level of hormones was found to induce the best callus formation Chaâbani et al. (2015).

Our findings imply that a medium containing plant growth regulator activates the phenylpropanoid pathway in which boosts the production of phenolic substances Johri and Mitra (2001). In the phenylpropanoid pathway, the most important enzyme is the phenylalanine ammonia-lyase enzyme which acts as the main biosynthesis of many phenolic compounds in plants such as the synthesis of 
phenolic, flavonoids, and lignin compounds Schuster and Retey (1995).

Reports are saying that the antioxidant activity has a direct relation with the number of phenolic compounds Krajnc et al. (2013), Dias et al. (2016). Some authors said that in response to biotic and abiotic elicitors, antioxidant activity and phenolic compounds in different plants have a positive association Vasco et al. (2008).

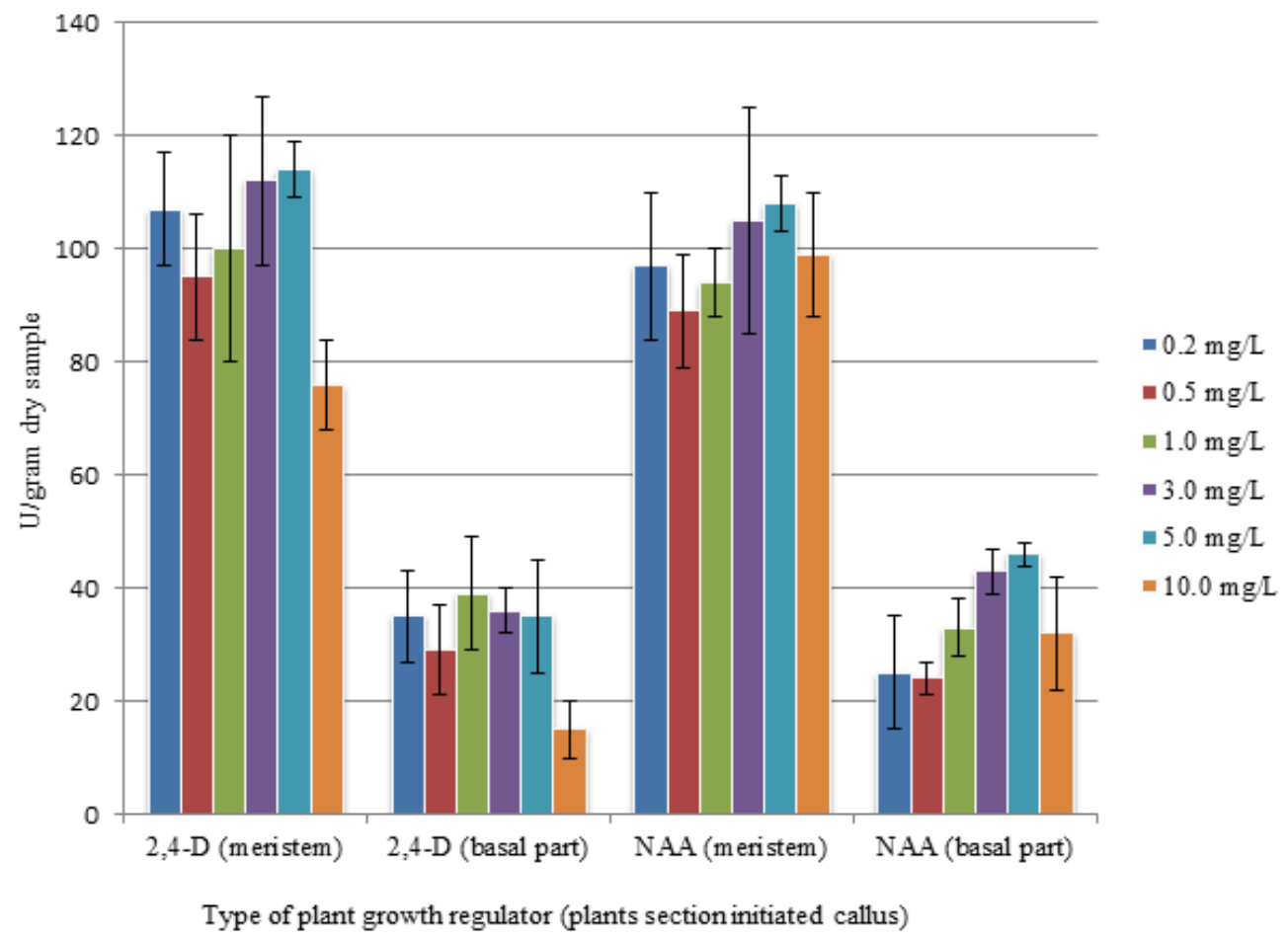

Figure 2 AntioxidantActivity in Callus of K. parviflora

\section{CONCLUSION}

High phenolic and antioxidant activity in the callus of K. parviflora can be obtained by using the meristem part from K. parviflora. The best medium for a high induction of total phenolic content and antioxidant activity as in callus culture for this plant was 2,4-D with a concentration of $10.0 \mathrm{mg} / \mathrm{L}$ and $5.0 \mathrm{mg} / \mathrm{L}$, respectively. The antioxidants in K. parviflora are vital and crucial for the human health and hence this research provided optimal concentration for callus of K. parviflora that are able to produce high antioxidant and further prove that meristems have better antioxidants content.

\section{REFERENCES}

Baluška, F., Volkmann, D., \& Menzel, D. (2005). Plant synapses: actin-based domains for cellto-cell communication. Trends in Plant Science, 10(3), 106-111. Retrieved from https:// dx.doi.org/10.1016/j.tplants.2005.01.002 10.1016/j.tplants.2005.01.002 
Britannica, T. (2020). Editors Of Encyclopaedia. Meristem. Encyclopedia Britannica. Retrieved from Https://Www.Britannica.Com/Science/Meristem

Chaâbani, G., Tabart, J., Kevers, C., Dommes, J., Khan, M. I., Zaoui, S., Chebchoub, L., Lachaâl, M., \& Karray-Bouraoui, N. (2015). Effects of 2,4-dichlorophenoxyacetic acid combined to 6-Benzylaminopurine on callus induction, total phenolic and ascorbic acid production, and antioxidant activities in leaf tissue cultures of Crataegus azarolus L. var. aronia. Acta Physiologiae Plantarum, 37(2), 16-16. Retrieved from https://dx.doi.org/ 10.1007/s11738-014-1769-4 10.1007/s11738-014-1769-4

Dias, M. I., Sousa, M. J., Alves, R. C., \& Ferreira, I. C. F. R. (2016). Exploring Plant Tissue Culture To Improve The Production Of Phenolic Compounds: A Review Ind Crop Prod., 82, 912.

El-Nabarawy, M. A., El-Kafafi, S. H., Hamza, M. A., \& Omar, M. A. (2015). The effect of some factors on stimulating the growth and production of active substances in Zingiber officinale callus cultures. Annals of Agricultural Sciences, 60(1), 1-9. Retrieved from https://dx.doi.org/10.1016/j.aoas.2014.11.020 10.1016/j.aoas.2014.11.020

Ghasemzadeh, A., Jaafar, H. Z. E., Rahmat, A., Wahab, P. E. M., \& Halim, M. R. A. (2010). Effect of Different Light Intensities on Total Phenolics and Flavonoids Synthesis and Antioxidant Activities in Young Ginger Varieties (Zingiber officinale Roscoe). International Journal of Molecular Sciences, 11(10), 3885-3897. Retrieved from https://dx.doi.org/ 10.3390/ijms11103885 10.3390/ijms11103885

Jiménez-Aspee, F., Theoduloz, C., Gómez-Alonso, S., Hermosín-Gutiérrez, I., Reyes, M., \& Schmeda-Hirschmann, G. (2018). Polyphenolic profile and antioxidant activity of meristem and leaves from "chagual" (Puya chilensis Mol.), a salad from central Chile. Food Research International, 114, 90-96. Retrieved from https://dx.doi.org/10.1016/ j.foodres.2018.07.051 10.1016/j.foodres.2018.07.051

Johari, M. A., \& Khong, H. Y. (2019). Total Phenolic Content and Antioxidant and Antibacterial Activities of Pereskia bleo. Advances in Pharmacological Sciences, 2019, 1-4. Retrieved from https://dx.doi.org/10.1155/2019/7428593 10.1155/2019/7428593

Johri, M. M., \& Mitra, D. (2001). Action Of Plant Hormones. Current Science, 199-205.

Krajnc, A. U., Turinek, M., \& Ivančič, A. (2013). Morphological And Physiological Changes During Adventitious Root Formation As Affected By Auxin Metabolism: Stimulatory Effect Of Auxin Containing Seaweed Extract Treatment. Agricultura, 10(1-2), 17-27.

MERCIER, H., KERBAUY, G. B., SOTTA, B., \& MIGINIAC, E. (1997). Effects of NO3-, NH4+ and urea nutrition on endogenous levels of IAA and four cytokinins in two epiphytic bromeliads. Plant, Cell and Environment, 20(3), 387-392. Retrieved from https://dx .doi.org/10.1046/j.1365-3040.1997.d01-72.x 10.1046/j.1365-3040.1997.d01-72.x

Pati, P. K., Rath, S. P., Sharma, M., Sood, A., \& Ahuja, P. S. (2006). In vitro propagation of rosea review. Biotechnology Advances, 24(1), 94-114. Retrieved from https://dx.doi.org/ 10.1016/j.biotechadv.2005.07.001 10.1016/j.biotechadv.2005.07.001

Prathanturarug, S., Apichartbutra, T., Chuakul, W., \& Saralamp, P. (2000). Mass Propagation Of Kaempferia Parviflora Wall Ex Baker By In Vitro Regeneration. Journal Of Horticultural Science And Biotechnology, 82, 179-183.

PRIHANTINI, A. I., SUKITO, A., \& TACHIBANA, S. (2018). Production of antioxidant compounds from tissue culture of Artemisia annua. Nusantara Bioscience, 10(4), 251255. Retrieved from https://dx.doi.org/10.13057/nusbiosci/n100409 10.13057/ nusbiosci/n100409

Rujjanawate, C., Kanjanapothi, D., Amornlerdpison, D., \& Pojanagaroon, S. (2005). Anti-gastric ulcer effect of Kaempferia parviflora. Journal of Ethnopharmacology, 102(1), 120-122. 
Retrieved from https://dx.doi.org/10.1016/j.jep.2005.03.035 10.1016/j.jep.2005.03 .035

Schuster, B., \& Retey, J. (1995). The mechanism of action of phenylalanine ammonia-lyase: the role of prosthetic dehydroalanine. Proceedings of the National Academy of Sciences, 92(18), 8433-8437. Retrieved from https://dx.doi.org/10.1073/pnas.92.18.8433 10 $.1073 /$ pnas.92.18.8433

Sumadi, S. (2020). DINAMIKA KONFLIK TOKOH DALAM NOVEL KIDUNG RINDU DI TAPAL BATASKARYA AGUK IRAWAN MN KAJIAN PSIKOLOGI SASTRA. In V. M. A. B. J. D. K. S. Kultivasi (Ed.), EDU-KATA (Vol. 6, pp. 19-26). Universitas Islam Darul Ulum Lamongan. Retrieved from https://dx.doi.org/10.52166/kata.v5i1.1789 10.52166/kata.v5i1 .1789

Tewtrakul, S., Subhadhirasakul, S., \& Kummee, S. (2008a). Anti-allergic activity of compounds from Kaempferia parviflora. Journal of Ethnopharmacology, 116(1), 191-193. Retrieved from https://dx.doi.org/10.1016/j.jep.2007.10.042 10.1016/j.jep.2007.10 .042

Tewtrakul, S., Subhadhirasakul, S., \& Kummee, S. (2008b). Anti-allergic activity of compounds from Kaempferia parviflora. Journal of Ethnopharmacology, 116(1), 191-193. Retrieved from https://dx.doi.org/10.1016/j.jep.2007.10.042 10.1016/j.jep.2007.10 .042

Vasco, C., Ruales, J., \& Kamal-Eldin, A. (2008). Total phenolic compounds and antioxidant capacities of major fruits from Ecuador. Food Chemistry, 111(4), 816-823. Retrieved from https://dx.doi.org/10.1016/j.foodchem.2008.04.054 10.1016/j.foodchem.2008 .04 .054

Vichitphan, S., Vichitphan, K., \& Sirikhansaeng, P. (2007). FLAVONOID CONTENT AND ANTIOXIDANT ACTIVITY OF KRACHAI-DUM. (Kaempferia Parviflora) WINE. S2 KMITL Sci. Tech. J,, 7(S2), 97-105. Retrieved from Https://Li01.Tci-Thaijo.Org/Index.Php/ Cast/Article/View/86819

Yenjai, C., Prasanphen, K., Daodee, S., Wongpanich, V., \& Kittakoop, P. (2004). Bioactive flavonoids from Kaempferia parviflora. Fitoterapia, 75(1), 89-92. Retrieved from https://dx.doi.org/10.1016/j.fitote.2003.08.017 10.1016/j.fitote.2003.08.017

Zuraida, A. R., Nazreena, O. A., Izzati, K. F. L., \& Aziz, A. (2014). Establishment and Optimization Growth of Shoot Buds-Derived Callus and Suspension Cell Cultures of \&lt;i\&gt;Kaempferia parviflora\&lt;/i\&gt;. American Journal of Plant Sciences, 05(18), 2693-2699. Retrieved from https://dx.doi.org/10.4236/ajps.2014.518284 10.4236/ ajps.2014.518284 